\title{
PENDIDIKAN AGAMA ISLAM DALAM KEBUDAYAAN MASYARAKAT KALANG
}

Oleh : Abdul Kholiq

Fakultas Ilmu Tarbiyah dan Keguruan Universitas Islam Negeri Walisongo Email : alchoolig@yahoo.com

\begin{abstract}
Abstrak
Kalang merupakan salah satu sub-etnis Jawa yang secara kebudayaan berbeda dengan Jawa. Makalah ini membahas tentang permasalahan bagaimana fungsi pendidikan agama Islam sebagai strategi kebudayaan bagi masyarakat Kalang; dan bagaimana adaptasinya akibat masuknya nilai-nilai Islam. Sebagai entitas budaya, Orang Kalang mengkonstruksi identitas kebudayannya berdasarkan nilai-nilai budaya yang diwarisi dari leluhurnya. Sistem kepercayaan Kalang mempunyai kesejarahan teologis dengan agama Jawa purba (Kapitayan). Kepercayaan ini melahirkan berbagai ritual Kalang seperti 'gegalungan', 'ewuhan' dan 'obong'. Melalui pendidikan agama, anakanak Kalang dapat mengenali nilai-nilai baru (Islam). Konsekuensi dari bertemunya nilai-nilai kebudayaan yang berbeda, paling tidak ada tiga kemungkinan yang terjadi, sebagai respon orang Kalang terhadap nilai-nilai baru tersebut, yaitu pertama; sistem nilai lama dimenangkan; kedua, sistem nilai baru dimenangkan; ketiga, terjadinya kompromi.
\end{abstract}

\section{Abstract}

Kalang is one of sub-ethnic Javanese, that's different to Java culturally. This study to explain about the function of islamic education as a cultural strategy for Kalang's society; and its adaptation its effect Islam values are entered. As cultural entity, Kalang's community build cultural identity based on cultural values inherited from ancestors. Kalang's belief system has a theological religion historical ancient Javanese (Kapitayan). This belief bears the ritual Kalang as 'gegalungan', 'emuban' and 'obong'. Through Islamic education, children's of Kalang can recognize the values of Islam. Consequence of meets it cultural values that variably, there are three possibilities occur, as response of Kalang's person to that new values, which is first; the old value system won, or the new value system won, or third occurance of compromise.

Key words: Kalang; Ethnic; Cultural; Islamic education.

\section{A. Latar Belakang}

Salah satu sub-etnis yang turut memperkaya kebhinekaan dan karakter bangsa Indonesia adalah suku Kalang. ${ }^{1}$ Sebagai kategori sosial, Kalang

1 Dalam perspektif historis, istilah kalang sendiri telah ditemukan dalam prasasti Kuburan Candi di Desa Tegalsasi Magelang yang berangka 753 saka atau 831 Masehi. 
mempunyai sejarah panjang, hanya saja rekaman historisnya terdengar samar-samar, karena sebagai kategori demografis, Kalang telah dihapuskan oleh Deandels pada awal abad ke-19 dan dimasukkan ke dalam golongan pribumi (Warto, 2011: 34). Demikian halnya, sebagai komunitas budaya, Kalang umumnya kurang dikenal sebagai komunitas budaya yang otonom karena dominasi supra-etnis Jawa. Padahal, seperti ditulis oleh Lombart (1999: 144), Kalang memiliki ciri khas yang memiliki syarat sebagai suatu entitas budaya yang otonom dan berbeda dengan Jawa.

Komunitas Kalang adalah bagian dari penduduk Jawa, diduga selama ratusan tahun pernah hidup dan menyebar di kawasan hutan jati di wilayah Jawa Timur dan Jawa Tengah (Warto, 2011: 35). Di wilayah Jawa Tengah, daerah yang tercatat sebagai wilayah konsentrasi orang Kalang adalah Rembang, Blora, Pati, Demak, Kendal, Pekalongan, Tegal (Raffles, 1978; dikutip dari Muslichin, 2008: 169). Menurut catatan VOC Tahun 1743, jumlah orang Kalang mencapai 2.780 keluarga. Secara geografis, mereka tersebar di berbagai daerah pesisir Jawa, seperti Surabaya (250 keluarga), Pasuruhan (50), Pati (250), Demak (1000), Pekalongan (800), Tegal (180) dan Kendal (250) (Ketjen, 1883: 7). Di luar itu, orang-orang Kalang juga bermukim di Cilacap, Adipala, Gombong, Ambar Karanganyar, Petanahan, Solo, Yogyakarta, Tulungagung dan Malang (Kesti, 1993; Sholeh, 2004: 8; Suara Merdeka, 31 Januari 2008).

Dalam sejarahnya, orang Kalang membangun askriptif ke-etnisannya berdasarkan cultural memory para pendukungnya (Jeanette \& Fortier: 2007). Pengetahuan kolektif Kalang yang berisikan sistem kepercayaan dan nilainilai budaya yang bersumber dari mitologi Kalang ditransmisikan dari generasi ke generasi melalui tradisi lisan sebagai strategi untuk menjaga kelangsungan hidupnya. Sistem kepercayaan Kalang berakar dari kesejarahan teologis yang berhubungan dengan agama Jawa purba yang bercorak animism-dinamisme. Dalam perkembangannya, sistem kepercayaan dan nilai-nilai budaya Kalang mengalami dinamika sejalan masuknya agama-agama besar ke Jawa. Ketika datang ajaran Hindu-Budha, orang Kalang melakukan pengadaptasian kepercayaan melalui akulturasi antara animisme-dinamisme dengan ajaran Hindu-Budha (Koentjaraningrat, 2002: 45). Pada saatnya Islam datang, sebagian orang-orang Kalang juga mengalami konversi memeluk Islam, meskipun melalui proses yang sangat

Diduga keberadaan mereka telah ada sejak sebelum Jawa memasuki zaman Hindu (Sholeh, 2004: 4). 
alot dan oleh Nakamura (1974) ditempatkan pada sisi keberagamaan yang eksrim (abangan). Seperti halnya agama Hindu dan Budha, kedatangan Islam tersebut tidak serta-merta mematikan keseluruhan kepercayaan dan adat istiadat yang dianut masyarakat Kalang. Proses perkawinan kepercayaan terjadi, yakni antara animisme-dinamisme, Hindu-Budha dan Islam. Konsekuensi dari singkretisme kepercayaan ini melahirkan suatu bentuk agama yang khas dan berbeda dengan lainnya. Agus Sunyoto berhipotesis, bahwa tidak satupun agama besar benar-benar sepenuhnya mampu mengganti agama asli Jawa (Sunyoto, 2012).

Salah satu aspek penting yang berpengaruh besar terhadap keberadaan suatu kebudayaan adalah pendidikan (Juanda, 2010: 1-2). Pendidikan dipahami sebagai proses transfer nilai (values), pengetahuan (knowledge) dan ketrampilan (skill) kepada generasi muda agar mampu hidup lebih baik (Azizy, 2002: 19). Dalam pengertian ini, pendidikan bisa berlangsung secara formal di sekolah, keluarga (informal) maupun masyarakat (non-formal). Dalam perspektif kebudayaan, praktek pendidikan terjadi di dalam interaksi antara manusia dalam suatu masyarakat yang berbudaya. Tidak ada pendidikan yang terjadi di arena yang vakum. Berdasarkan pandangan tersebut, kebudayaan mempunyai keterkaitan dengan pendidikan. Dalam keterkaitan tersebut, Tilaar (2002:7) berargumentasi, apabila kebudayaan dipahami berdasarkan rumusan Tylor di mana kebudayaan mempunyai tiga unsur penting yaitu kebudayaan sebagai suatu tata kelola kehidupan (order), kebudayaan sebagai suatu proses dan kebudayaan yang mempunyai suatu visi tertentu (goals), maka pendidikan dalam rumusan tersebut adalah sebenarnya proses pembudayaan. Oleh karena itu antara pendidikan dan kebudayaan mempunyai hubungan yang sangat erat dan berbicara pada tataran yang sama, yaitu nilai-nilai (Pai, 1990: 3; Tilaar, 2002a: 5).

Mengacu pada pandangan di atas, keberadaan dan kelangsungan sistem kepercayaan dan kebudayaan Kalang sangat dipengaruhi oleh pendidikan. Regulasi pemerintah yang menerapkan kebijakan 'wajib belajar 9 tahun' dan meningkatnya tuntutan kehidupan akibat perkembangan zaman, menyebabkan masyarakat Kalang menerima pendidikan sebagai 'keniscayaan'. Melalui pendidikan formal, anak-anak Kalang bersentuhan dengan nilai-nilai baru yang didapatinya dari sekolah. Dari sekolah pula, mereka bersentuhan dengan nilai-nilai agama formal sebagai nilai baru akibat regulasi Negara yang mewajibkan pengajaran agama formal di sekolah. Selain sekolah, arus modernisasi turut menjadi salah satu faktor penting terjadinya dinamika sosial budaya Kalang. Nilai-nilai modernitas 
(baru) telah masuk dalam memori kolektif orang Kalang melalui kemajuan teknologi seperti televisi, radio ataupun internet. Masyarakat Kalang yang tidak lagi menerapkan sistem proteksi, cenderung membuka diri bagi masuknya pengaruh luar. Masuknya pengaruh nilai-nilai dari luar mendorong terjadinya proses akulturasi kebudayaan. Konsekuensi dari bertemunya nilai-nilai kebudayaan yang berbeda, paling tidak ada tiga kemungkinan yang terjadi. Pertama, sistem nilai lama dimenangkan dari sistem nilai baru; kedua, sistem nilai baru mengalahkan sistem nilai lama; ketiga, terjadinya kompromi (Damami, 2000: 9).

\section{B. Rumusan Masalah}

Adapun masalah dalam makalah ini dapat dirumuskan sebagai berikut:

1) Bagaimana fungsi pendidikan agama Islam sebagai strategi kebudayaan?

2) Bagaimana budaya Kalang dan adaptasinya akibat masuknya nilai-nilai Islam?

\section{Pembahasan}

\section{Konsepsi Pendidikan Islam}

Pendidikan secara etimologi disepadankan dengan istilah pedagogi, dari bahasa Yunani yang berasal dari asal kata paid artinya anak dan agogos artinya membimbing; sehingga pedagogi dapat diartikan sebagai ilmu dan seni mengajar anak (Juanda, 2010: 3; Sukarjo \& Komaruddin, 2009: 7). Dalam bahasa Inggris, pendidikan disepadankan dengan kata education yang artinya lebih menekankan unsur pengajaran (instruction) (Tafsir, 2005: 24). Dalam konteks tersebut, perspektif Barat umumnya mendefinisikan pendidikan sebagai "the process of training and developing the knowledge, skill, mind, character ect., especially by formal schooling”'(Azizy, 2002: 18). Menurut Undang-undang Sistem Pendidikan Nasional nomor 20 tahun 2003 pasal 1 ayat (1): "Pendidikan adalah usaha sadar dan terencana untuk mewujudkan suasana belajar dan proses pembelajaran agar peserta didik secara aktif mengembangkan potensi dirinya untuk memiliki kekuatan spiritual keagamaan, pengendalian diri, kepribadian, kecerdasan, akhlak mulia, serta keterampilan yang diperlukan dirinya, masyarakat, bangsa dan negara."

Dalam khazanah Islam, istilah pendidikan dikenal istilah tarbiyah, tabdrib dan ta'lim (Muhaimin, 2001: 35-38; Fajar, 1999: 79). Istilah tarbiyah berakar dari kata rabba yang berarti mendidik, mengasuh dan memelihara. Kata yang serumpun rabba yang memiliki arti memperbaiki, menambah atau berkembang (Daradjat, 2006: 25-26; Achmadi, 2005: 25). Istilah ta'lim merupakan masdar dari kata 'allama yang berarti pengajaran yang bersifat 
pemberian atau penyampaian pengetahuan dan ketrampilan (Achmadi, 2005: 25; Ramayulis, 2008: 14). Sedangkan istilah ta'dib yang lazimnya diterjemahkan dengan pendidikan sopan santun, tata karma, adab, budi pekerti, moral, etika dan akhlak (Abuddinnata, 2010: 14).

Bertolak dari berbagai pandangan etimologis tentang pendidikan seperti di atas, para ahli memberikan batasan tentang pendidikan Islam secara beragam. Muhammad al Syaibany mendefinisikan pendidikan Islam sebagai usaha mengubah tingkah laku individu dalam kehidupan pribadinya atau kehidupan kemasyarakatannya dan kehidupan dalam alam sekitarnya melalui proses kependidikan, perubahan itu dilandasi dengan nilai nilai islami (Al Syaibani, 1979: 399). Qardawi memberikan pengertian tentang pendidikan Islam adalah pendidikan manusia seutuhnya, akal dan hatinya, rohani dan jasmanisnya, akhlak dan ketrampilannya (Qardawi dalam Azra, 2012: 6). Achmadi memberikan definisi pendidikan Islam sebagai segala usaha untuk memelihara dan mengembangkan fitrah manusia serta sumber daya manusia yang ada padanya menuju terbentuknya manusia seutuhnya (insan kamil) sesuai dengan norma Islam (Achmadi, 2005: 28-29). Syaifuddin Anshari mendefinisikan pendidikan Islam sebagai proses bimbingan (pimpinan, tuntutan, usulan) oleh subjek didik terhadap perkembangan jiwa (pikiran, perasaan, kemauan dan intuisi) dan raga objek didik dengan bahan materi tertentu, pada jangka waktu tertentu, metode tertentu dan dengan alat perlengkapan yang ada ke arah terciptanya pribadi tertentu disertai evaluasi sesuai ajaran Islam (Anshari dalam Azra, 2012:6-7). Secara lebih rinci, definisi-definisi tentang pendidikan Islam di atas dapat disimpulkan sebagai berikut: 1) aktifitas yang berhubungan dengan merubah tingkah laku; 2) melibatkan potensi akal, hati (rohani) dan jasmani; 3) melalui proses kependidikan yang direncanakan baik tujuan, metode dan evaluasinya; 4) dijiwai dengan nilai-nilai Islam; dan 5) berorientasi pada keseimbangan kehidupan di dunia dan akherat.

Pendidikan Agama Islam diarahkan pada pencapaian tujuan yang telah dirumuskan berdasarkan sumber al Quran dan sunnah serta berlandaskan hakekat keberadaan manusia sendiri sebagaimana konsepsinya dalam Islam (Umiarso dan Zamroni, 2011: 104). Tujuan pendidikan Islam secara universal ditetapkan oleh konggres sedunia tentang pendidikan Islam $^{2}$ seperti dikutip Abuddin Nata (2010: 62; Achmadi, 2005: 101) sebagai berikut:

\footnotetext{
${ }^{2}$ Konferensi Internasional I di Makkah tanggal 8 April 1977.
} 
"Education should aim at the balanced growth of total personality of man through the training of man's spirit, intellect the rational self, feeling and bodily sense. Education should therefore cater for the growth of man in all its aspects, spiritual, intellectual, imaginative, physical, scientific, linguistic, both individual and collectively, and motivate all these aspects toward goodness and attainment of perfection. The ultimate aim of education lies in the realization of complete submission to Allab on the level individual, the community and humanity at large".

Menurut Abuddin Nata (2010: 62) tujuan pendidikan Islam yang bersifat universal di atas sesungguhnya dirumuskan berdasarkan dari berbagai pendapat para pakar pendidikan, seperti Al Attas yang merumuskan tujuan pendidikan Islam menjadi manusia yang baik (Al Attas, 1979: 1), Athiyah al Abrary yang menghendaki manusia yang berakhlak mulia (Al Abrasy, 1974: 15). Munir Mursi, terbentuknya manusia sempurna (insan kamil) (Mursi, 1977: 18), Ahmad D Marimba, terbentuknya manusia yang berkepribadian muslim (Marimba, 1989: 39), Muhammad Qutub, terbentuknya manusia yang mampu menjalankan fungsinya sebagai hamba Allah dan khalifatullah (Qutub, t.th: 13) dan sebagainya.

Secara lebih spesifik Achmadi (2005: 94-105) membagi tujuan pendidikan Islam dalam beberapa tingkatan (tahapan). Pertama: tujuan tertinggi, yakni tujuan yang bersifat mutlak, tidak mengalami perubahan karena sesuai dengan konsep Ilahi yang mengandung kebenaran mutlak dan universal. Tujuan tersebut meliputi: a) menjadi hamba Allah yang bertaqwa; b) mengantarkan subjek didik menjadi khalifatullah fil ardhi; c) memperoleh kesejahteraan, kebahagiaan hidup di dunia dan di akhirat. Kedua: tujuan umum yakni tujuan yang lebih bersifat empirik dan realistik dan berfungsi sebagai arah yang taraf pencapaiannya dapat diukur karena menyangkut perubahan sikap, perilaku dan kepribadian subjek didik sehingga mampu menghadirkan dirinya sebagai sebuah pribadi yang utuh atau disebut sebagai realisasi diri (self realization). Wujud aktual dari realisasi diri ini adalah manusia dewasa, artinya manusia yang mampu merealisasikan dirinya secara bertanggung jawab atas segala perbuatannya yang dapat diukur pencapaiannya pada tiga realitas, yakni realitas subyektif ${ }^{3}$, realitas simbolik ${ }^{4}$ dan realitas objektif. ${ }^{5}$ Ketiga: tujuan khusus, yaitu pengkhususan atau

\footnotetext{
${ }^{3}$ Realitas subjektif berisikan nilai-nilai yang bersumber dari al Quran dan Hadis.

${ }^{4}$ Realitas simbolik merupakan bentuk aktualisasi diri yang berupa simbol-simbol seperti cara berpakaian, amalan sehari-hari dan sebagainya.

${ }^{5}$ Realitas objektif adalah situasi dan kondisi dari realitas kehidupan yang syarat dengan berbagai persoalan kehidupan.
} 
operasionalisasi tujuan tertinggi dan terakhir dan tujuan umum pendidikan Islam. Tujuan ini bersifat relative dan dimungkinkan disesuaikan dengan kultur dan cita-cita suatu bangsa; minat, bakat dan kesanggupan subjek didik; situasi dan kondisi pada kurun waktu tertentu. Termasuk dalam kategori tujuan ini adalah tujuan pendidikan agama Islam dalam Sistem Pendidikan Nasional.

\section{Pendidikan Agama Islam: Internalisasi Nilai-Nilai Islam}

Secara etimologis, internalisasi diartikan sebagai penghayatan, pendalaman, penguasaan secara mendalam yang berlangsung melalui binaan, bimbingan dan sebagainya (Kamus Besar Bahasa Indonesia, 1989: 336). Dalam perspektif psikologis, internalisasi diartikan sebagai penggabungan atau penyatuan sikap, standar tingkah laku, pendapat dan seterusnya di dalam kepribadian (Chaplin, 2002 : 256). Internalisasi nilai-nilai agama dimaksudkan sebagai pembinaan yang mendalam dan menghayati nilai-nilai (agama) yang dipadukan dengan nilai-nilai pendidikan secara utuh yang sasarannya menyatu dalam kepribadian peserta didik, sehingga menjadi satu karakter atau watak peserta didik.

Nilai sendiri menurut Gazalba (dalam Thoha, 1996 : 61) adalah sesuatu yang bersifat abstrak, ia ideal, bukan benda kongkrit, bukan fakta, bukan hanya persoalan benar dan salah yang menuntut pembuktian empirik, melainkan soal penghayatan yang dikehendaki dan tidak di kehendaki, disenangi dan tidak disenangi. Darajat, dkk., (1994: 260), memberikan pengertian bahwa nilai adalah suatu perangkat keyakinan ataupun perasaan yang diyakini sebagai suatu identitas yang memberikan corak yang khusus kepada pola pemikiran perasaan, keterikatan, maupun perilaku. Sedangkan nilai-nilai Islam merupakan keyakinan atau perasaan yang dibangun berdasarkan aturan-aturan Allah yang antara lain aturan yang mengatur tentang hubungan manusia dengan Allah, manusia dengan manusia dan manusia dengan alam secara keseluruhan (Hakim, 2012: 69).

Menurut Muhaimin (1996: 153) proses internalisasi nilai-nilai agama pada peserta didik setidaknya melalui tiga tahap, yaitu: a) tahap transformasi nilai; tahap ini merupakan suatu proses dalam menginformasikan nilai-nilai agama secara verbal antara pendidik dan peserta didik. b) tahap transaksi nilai, yaitu tahap pendidikan nilai dengan jalan melakukan komunikasi dua arah atau interaksi (timbal balik) antara peserta didik dengan pendidik. c) tahap transinternalisasi; yakni tahap yang jauh lebih mendalam dari tahap transaksi. Pada tahap ini bukan hanya dilakukan dengan komunikasi verbal 
tapi juga sikap mental dan kepribadian. Jadi pada tahap ini komunikasi kepribadian yang berperan secara aktif.

Dengan meminjam teori Lickona seperti dikutip oleh Narmoatmojo (2010: 11) bahwa proses internalisasi nilai melalui tahap knowing, loving, desiring dan acting, maka internalisasi nilai-nilai keislaman dalam pendidikan agama Islam melalui tahap mengenali nilai-nilai Islam dan mengarahkan pada mencintai nilai-nilai Islam, kemudian menumbuhkan keinginan untuk mengamalkan nilai-nilai Islam dan akhirnya benar-benar mampu menjalankan nilai-nilai Islam.

Jika mengacu pada ranah afektif sebagai pijakan untuk mengukur keberhasilan pendidikan, menurut Krathwohl (1961; dikutip dari Zubaidi, 2011: 26-28) tingkatan ranah afektif terdiri dari lima tahap yaitu; pertama: receiving (attending). Pada tingkat ini dapat dirinci dalam tiga tahapan yakni kesiapan untuk menerima (awareness), kemauan untuk menerima (willingness to receive) dan mengkhususkan perhatian (selected attention). Kedua; responding, yakni aksi terhadap stimulus yang meliputi kesiapan menanggapi (acquiescene to responding), kemauan menanggapi (willingness to respond) dan kepuasan menanggapi (satisfaction in response). Ketiga; penilaian (valuing), mulai muncul internalisasi untuk memiliki dan menghayati nilai yang tahap ini terbagi dalam tiga tahap, yakni menerima nilai (acceptance of value), menyeleksi nilai yang disenangi (preference of value) dan komitmen terhadap suatu nilai. Keempat; pengorganisasian (organization), yakni tahap penyusunan nilai-nilai yang relevan menjadi sistem nilai. Proses ini dalam dua tahapan yakni konseptualisasi nilai dan pengorganisasian sistem nilai. Kelima; karakterisasi (characterization), yakni kemampuan untuk menghayati atau mempribadikan sistem nilai. Proses ini terdiri dari dua tahap, yakni generalisasi yaitu kemampuan melihat suatu masalah dari sudut pandang tertentu dan karakterisasi, yaitu mengembangkan pandangan hidup tertentu yang memberikan corak tersendiri pada kepribadian diri yang bersangkutan. Pada tingkat ini peserta didik memiliki sistem nilai yang mengendalikan perilaku sampai pada waktu tertentu hingga terbentuk gaya hidup. Hasil pembelajaran pada tingkat ini berkaitan dengan pribadi, emosi, dan sosial.

Berdasarkan paparan di atas bahwa pendidikan agama Islam dapat disebut sebagai proses internalisasi nilai-nilai keislaman jika dapat membawa anak untuk melakukan penghayatan sehingga mampu menyusun sistem nilai dan kemudian menjadi dasar bagi pembentukan pribadi anak yang bersangkutan. Jika tidak demikian, maka pendidikan agama Islam hanya bisa 
disebut sebagai ‘pengajaran' yang orientasinya sebatas membawa anak tahu dan paham tentang ajaran agama Islam.

\section{Pendekatan Budaya dalam Pendidikan Agama Islam}

Sebagaimana dijelaskan di atas bahwa pendidikan agama sesungguhnya adalah wahana untuk 'perubahan' bagi terbentuknya pribadipribadi muslim sehingga nilai-nilai Islam terefleksikan dalam perilaku seharihari. Melalui internalisasi nilai-nilai keislaman, sesungguhnya pendidikan agama Islam berorientasi pada proses pembentukan moral masyarakat yang islami. Dalam konteks ini sesungguhnya pendidikan agama Islam mengarah pada pembentukan kebudayaan yang islami. Pendidikan dalam perspektif pembudayaan dijelaskan oleh Young Pai (1990: 2): “... it can be viewed as the deliberate means by which each society attempts to transmit and perpetuate its notion of the good life, which is derived from the society's fundamental beliefs concerning the nature of the world, knowledge and values". (ini dapat dipandang sebagai cara sadar bahwa setiap masyarakat berusaha untuk mewariskan dan mengabadikan harapan hidup baik, yang diperoleh dari kepercayaan fundamental masyarakat mengenai sifat alami dunia, pengetahuan dan nilai). Dari perspektif ini, sesungguhnya pendidikan Islam adalah proses pembudayaan karena di dalamnya berisikan komitmen tentang fasilitasi dan langkahlangkah yang seharusnya dilakukan untuk mengarahkan peserta didik pada nilai-nilai (values) dan kebajikan (virtues) yang akan membentuknya menjadi manusia-manusia yang baik (good people) (Zubaedi, 2011: 29). Nilai-nilai tersebut kemudian menjadi referensi bagi kehidupan individu baik secara pribadi maupun masyarakat. Dengan kata lain sesungguhnya pendidikan agama Islam merupakan 'strategi kebudayaan' untuk membangun suatu tata kehidupan masyarakat berdasarkan nilai-nilai Islam.

Proses pendidikan agama Islam disebut sebagai proses pembudayaan karena melalui pendidikan tersebut, peserta didik menerima nilai-nilai Islam yang pada akhirnya membangun pola tindakan (pattern for behaviour) sebagai pijakan dalam berbudaya (Mudjahirin, 2007). Proses pendidikan sebagai gejala pembudayaan memang tidak mudah untuk dibangun pada setiap individu maupun kelompok karena dalam prosesnya banyak faktor yang mempengaruhi. Faktor tersebut terkait dengan realitas social yang bersifat subjektif yang dimiliki oleh individu-individu dan realitas objektif di luar individu yang mempunyai pengaruh kuat (Zubaedi, 2011: 198). Oleh karena itu dalam proses pendidikan agama Islam sebagai proses pembudayaan haruslah diperhatikan latar social-budaya dari peserta didik. 
Pendekatan budaya dimaksudkan sebagai cara pandang yang mendasari guru atau pendidik untuk menyusun strategi, model, metode ataupun alat pembelajaran dengan mempertimbangkan kondisi sosiokultural peserta didik. Melalui pendekatan ini, proses pendidikan agama akan mendapatkan konteksnya, karena berkaitan dengan realitas subjektif anak, yakni nilai-nilai yang sudah diyakini sebelumnya, sehingga memudahkan anak untuk menerima dan mengadaptasikannya. Demikian halnya, pendekatan ini juga akan menghantarkan pendidikan agama Islam menjadi 'bermakna', karena berkaitan dengan relaitas objektif anak, berkaitan dengan pemecahan masalah yang dihadapi masyarakat.

Dengan pendekatan budaya, pendidikan agama Islam tidak sekedar menyampaikan aspek kognitif yang bersisikan ajaran agama, tetapi proses pembudayaan yang dibangun berdasarkan nilai-nilai islam yang diinternasisasikan dengan mempertimbangkan realitas sosial-budaya siswa, baik realitas subjektif maupun objektif. Oleh karena itu, proses pembudayaan melalui pendidikan sesungguhnya membutuhkan pendekatan yang tepat untuk menanamkan nilai-nilai Islam sebagai pijakan bagi pola tindakan (pattern for behaviour) anak didik sehingga mereka bisa tumbuh menjadi pribadi-pribadi yang mempunyai kepribadian muslim.

\section{Pendidikan Agama Islam sebagai Strategi Kebudayaan}

Sebelum sampai pada pembahasan pendidikan agama sebagai strategi kebudayaan, perlu terlebih dahulu diuraikan kedudukan agama dalam sistem budaya. Dakam konteks kebudayaan, agama dipahami sebagai suatu sistem keyakinan dan tindakan yang diwujudkan oleh suatu kelompok atau masyarakat dalam menginterpretasikan dan memberikan tanggapan terhadap apa yang dirasakan dan diyakini sebagai gaib dan suci (Zubair, 1995: 2; Mudjahirin, 2006: 1). Agama sebagai sistem keyakinan dapat menjadi bagian dalam sistem nilai yang ada dalam kebudayaan dari masyarakat yang bersangkutan, menjadi pendorong sekaligus pengendali bagi tindakantindakan anggota masyarakat tersebut agar tetap sesuai dengan nilai-nilai agama dan kebudayaannya (Suparlan, 1986).

Sebagai sistem normatif, agama dapat berpengaruh kuat terhadap sistem kebudayaan. Menurut Clifford Geertz (1992: 5) agama dalam kebudayaan dapat berfungsi sebagai: 1) sistem simbolik yang berfungsi dalam mengatur keputusan tindakan manusia; 2) untuk memantapkan, meresapkan perasaan-perasaan, motivasi-motivasi secara kuat, menyeluruh dan bertahan lama dalam diri manusia; 3) dengan cara memformulasikan 
konsepsi-konsepsi keteraturan kehidupan dan 4) menyelimuti konsepsikonsepsi tersebut dengan aura tertentu; 5) sehingga perasaan-perasaan dan motivasi-motivasi tersebut tampak bersifat nyata. Berdasarkan pandangan di atas, sesungguhnya agama dengan sistem normatifnya mengatur seluruh bidang kehidupan manusia.

Dalam konteks pendidikan nasional, fungsi dan tujuan pendidikan nasional sebagaimana dijelaskan pada bab II pasal 3 UU Sisdiknas 2003 sebagai berikut:

"Pendidikan nasional berfungsi mengembangkan kemampuan dan membentuk watak serta peradaban bangsa yang bermartabat dalam rangka mencerdaskan kehidupan bangsa bertujuan untuk berkembangnya potensi peserta didik agar menjadi manusia yang beriman dan bertakwa kepada Tuhan Yang Maha Esa, berakhlak mulia, sehat, berilmu, cakap, kreatif, mandiri dan menjadi warga Negara yang demokratis serta bertanggung jawab."

Jika dicermati ketentuan pasal di atas, tampak bahwa pendidikan nasional merupakan strategi dalam mewujudkan kebudayaan dan peradaban bangsa Indonesia yang bermartabat. Indikator watak dan peradaban bermartabat itu sendiri tentunya adalah ketika terbentuk gererasi yang betulbetul menghargai dan menghormati sistem nilai kebudayaan bangsanya. Pada bagian lain, tujuan pendidikan nasional yang berorietasi pada pengembangan potensi anak menjadi manusia yang beriman dan bertaqwa kepada Tuhan Yang Maha Esa mengindikasikan 'nilai agama' mempunyai kedudukan penting, menjadi bagian dari watak dan peradaban bangsa Indonesia. Oleh karena itu salah satu strategi dalam mengembangkan kebudayaan dan peradaban bangsa Indonesia yang 'religius', pemerintah menetapkan pendidikan agama sebagai sub sistem pendidikan nasional, yang dimaksudkan untuk membentuk peserta didik menjadi manusia yang beriman dan bertakwa kepada Tuhan Yang Maha Esa serta berakhlak mulia.

Dalam konteks kebudayaan, pendidikan agama dapat dipahami sebagai proses pembudayaan untuk mentahbiskan seseorang mampu hidup dengan mempunyai pandangan hidup, sikap hidup dan ketrampilan hidup sesuai dengan ajaran agama yang dianutnya dalam suatu budaya tertentu. Oleh karena itu pendidikan agama dapat dikatakan sebagai strategi kebudayaan dalam kehidupan masyarakat Indonesia.

Menurut Muhaimin (2008: 76), pendidikan (agama) Islam tidak saja diarahkan untuk meningkatkan keyakinan, pemahaman, penghayatan dan pengamalan ajaran agama Islam dari peserta didik, yang di samping untuk 
membentuk kesalehan personal, sekaligus membentuk kesalehan sosial. Kesalehan personal tersebut diharapkan dapat berimplikasi pada kesalehan sosial, artinya mampu menjaga hubungan baik dengan masyarakat, baik yang seagama ataupun yang tidak seagama, serta dalam berbangsa dan bernegara sehingga dapat terwujud persatuan dan kesatuan nasional bahkan ukhuwah insaniyah.

Dalam konteks masyarakat Indonesia yang pluralistik, baik agama, ras, etnis, tradisi, budaya dan sebagainya, adalah sangat rentan terhadap timbulnya konflik yang bersifat horizontal (Elizabeth, 2007: 12-13). Konteks yang demikian, menuntut pendidikan agama Islam haruslah mampu 'memutus' tumbuhnya fanatisme dan sikap intoleran di kalangan masyarakat 'agama' yang dapat memperlemah kerukunan hidup (Menteri Agama RI, 1996). Menurut Muhaimin (2008: 77) bahwa masyarakat yang plural, seperti Indonesia membutuhkan ikatan keadaban (the bound of civility). Artinya, pergaulan antara satu sama lain yang diikat dengan suatu 'civility' (keadaban). Ikatan ini pada dasarnya dapat dibangun dari nilai-nilai universal ajaran agama. ${ }^{6}$

Berdasarkan pandangan di atas, kebijakan pendidikan agama Islam diarahkan untuk menguatkan the bound civility, untuk mewujudkan kerukunan, kedamaian dan tercipta kebersamaan hidup serta toleransi yang dinamis dalam membangun bangsa Indonesia. Salah satu instrument penting yang menentukan pendidikan agama mampu atau tidaknya berfungsi menjadi agen the bound civility, adalah bagaimana guru agama mampu membelajarkan pendidikan agama yang difungsikan sebagai panduan dalam kehidupan masyarakat yang pluralis dan bagaimana guru agama mampu mengangkat dimensi-dimensi konseptual dan substansial dari ajaran agama seperti kejujuran, keadilan, kebersamaan, kesadaran akan hak dan kewajiban, ketulusan dalam beramal dan sebagainya untuk diaktualisasikan dan direalisasikan dalam kehidupan masyarakat Indonesia yang pluralis.

\section{Pendidikan Agama dalam Budaya Kalang : Akulturasi Budaya}

Regulasi pendidikan yang mengharuskan setiap lembaga pendidikan untuk mengajarkan mata pelajaran agama mendorong anak-anak Kalang bersentuhan dengan nilai-nilai Islam. Bersamaan dengan semakin meningkatknya kesadaran masyarakat Kalang untuk mengirimkan anakanaknya ke sekolah merupakan fase penting bagi dinamika budaya

\footnotetext{
${ }^{6}$ Pada prinsipnya, Islam mengajarkan kedamaian, kerukunan dan persaudaraan.
} 
masyarakat Kalang. Hal ini mengakibatkan anak-anak Kalang semakin intensif bersinggungan dengan nilai-nilai Islam, karena mereka secara reguler menerima matapelajaran Agama Islam di sekolahnya.

Dalam perspektif kebudayaan, perjumpaan dua sistem kebudayaan antara Islam dan Kalang telah melahirkan 'dialektika budaya' yang menghadapkan antara nilai-nilai budaya keduanya. Transmisi nilai-nilai dan sistem kepercayaan Islam yang didukung oleh instrumen politik baik melalui sejarah politik kesultanan Islam (Demak dan Mataram) maupun regulasi pemerintah yang menetapkan pendidikan agama sebagai instrumen pokok dalam sistem pendidikan Nasional menjadikan Islam sebagai kekuatan budaya besar (great tradition) dan berpengaruh besar terhadap terjadinya dinamika sosial-keagamaan masyarakat Kalang. Transmisi nilai-nilai keislaman mendapatkan tempatnya pada konteks sosial-budaya lokalitas Kalang dan pada akhirnya mempengaruhi budaya Kalang itu sendiri (Kholiq, 2012: 222-223).

Persilangan antara nilai-nilai Islam dan Kalang membawa konsekuensi terjadinya 'akulturasi' budaya. Akulturasi dikenal dengan nama kontak budaya, yaitu suatu proses yang muncul dalam lingkungan sosial tertentu karena dihadapkan dengan adanya beberapa unsur budaya asing. Unsurunsur kebudayaan asing itu secara perlahan diterima dan diolah disesuaikan dengan keinginan kebudayaannya sendiri. Menurut Bee (1974; Muslichin, 2008: 35) terdapat tiga perbedaan langkah dalam proses akulturasi, yaitu: pertama; disebut difusi. Proses akulturasi harus merupakan transmisi beberapa idea atau ciri-ciri. Kedua; evaluasi oleh pihak penerima. Beberapa ide atau ciri yang ditularkan melalui berbagai seleksi persepsual dan interpretative. Ketiga; adalah integrasi berbagai macam ide atau ciri-ciri yang telah diseleksi dan akan diterima, harus diintegrasikan ke dalam sistem budayanya sendiri.

Terhadap masuknya nilai-nilai Islam, masyarakat Kalang meresponnya secara beragam, pasalnya tidak setiap orang Kalang mempunyai persepsi dan apresiasi yang sama. Sebagian orang Kalang menganggap bahwa nilai-nilai baru (Islam) tidak bertentangan dengan nilai-nilai lama, sehingga keduanya dapat disandingkan secara harmoni. Sebagiannya lagi menganggap bahwa nilai-nilai baru benar-benar bisa menggantikan nilai lama, sehingga mereka rela mensublimasikan identitas budaya lamanya dalam identitas baru berdasarkan nilai-nilai baru yang diyakininya. Sebagian orang Kalang menilai bahwa nilai-nilai baru (Islam) merupakan ancaman terhadap nilai-nilai dan sistem kebudayaan yang mereka yakini, sehingga mereka berupaya untuk 
melakukan berbagai resistensi agar identitasnya tidak terancam oleh nilainilai baru. Penolakan itu dikarenakan ada hal yang baru itu dianggapnya tidak memiliki kejelasan fungsi. Dalam hal ini Parsons (1949: 536) mengatakan bahwa semua kompleks unsur asing itu dapat diterima hanya apabila berbagai unsur itu dapat disesuaikan dengan bentuk tingkah laku yang lama dan sesuai dengan berbagai sikap emosional yang sudah ada. Sebaliknya Kroeber (1948; Koentjaraningrat, 1958: 449) mengatakan bahwa suatu unsur kebudayaan asli tidak mudah dapat diganti, tanpa diintegrasikan ke dalam prinsip budaya yang ada.

Proses akulturasi budaya terjadi tergantung bagaimana cara masyarakat Kalang berinteraksi dengan masyarakat dominan (Islam). Menurut Berry dan Kim (1989; dikutip dari Muslichin, 2008: 37) setidaknya terdapat dua persoalan pokok yang perlu direspon oleh masyarakat Kalang dalam berinteraksi dengan masyarakat dominan. Pertama; berhubungan dengan persoalan pelestarian jati diri dan ciri budaya. Kedua; berhubungan dengan persoalan memelihara hubungan dengan kelompok lain. Ketika persoalan inti itu ditampilkan bersama maka suatu kerangka kerja konseptual tersebut dapat digambarkan sebagai berikut:

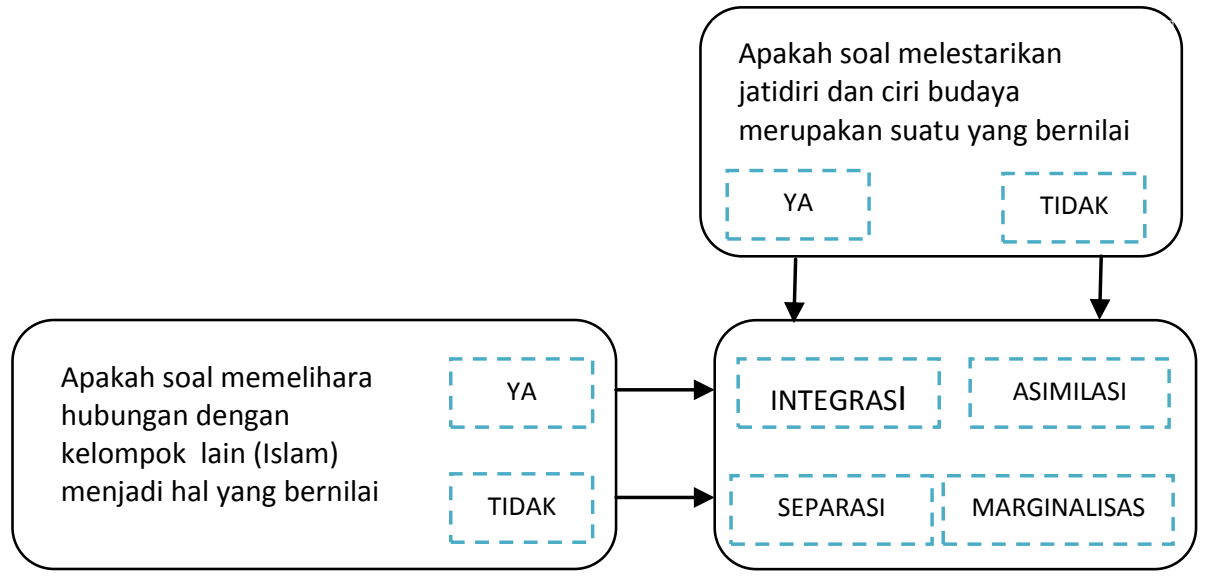

Gambar : Kerangka kerja akulturasi (Sumber: Berry, 1999: 541)

Gambar di atas, dapat dijelaskan bahwa ketika masyarakat tradisional (Kalang) bertemu dengan kelompok masyarakat yang memiliki dominasi kebudayaan (Islam), maka mereka akan memilih apakah tidak peduli dengan tradisinya sekaligus lingkungannya, berarti meminggirkan posisi dirinya (marginalisasi) atau mereka akan menyerah dan mengikuti semua yang ditawarkan oleh budaya dominan (asimilasi) atau mereka akan menggabungkan apa yang dimilikinya sembari mencari sisi kesamaan antara 
budayanya dengan budaya kelompok dominan (integrasi) atau sengaja menghindari interaksi dengan orang lain dalam rangka mempertahankan pengukuhan budaya dan nilai-nilainya (separasi).

Berdasarkan analisis di atas, gejala munculnya integrasi dalam akulturasi budaya Kalang dengan Islam dapat dilihat pada penyelenggaraan 'upacara Obang'. Dalam penyelenggaraan ritual Obong di Kendal misalnya, masyarakat Kalang menyertakan kyai untuk memimpin tablil dan do'a keselamatan bagi arwah. Ritual (Islam) ini biasanya diselenggarakan sebelum prosesi ritual Obong dimulai (Sholeh, 2004: 113). Fenomena ini menunjukkan bahwa nilai-nilai keislaman mendapatkan tempat dalam adat lokalitas Kalang sebagai sebuah proses reproduksi kebudayaan. Gejala ini memang bisa dimaknai sebagai wujud kompromi kebudayaan dimana Islam dan Kalang tidak sepenuhnya harus bersifat konfrontatif.

Dalam perspektif yang berbeda, sikap 'kompromi' dengan melakukan adaptasi kebudayaan yang dilakukan orang Kalang tersebut sebenarnya juga bisa dimaknai sebagai bentuk 'resistensi' budaya atas arus budaya Islam yang mereka pandang sangat besar. Bagi mereka, melawan kekuatan Islam adalah sesuatu yang tidak mungkin. Maka agar tetap bisa mempertahankan identitas mereka sebagai entitas sosio-kultural Kalang, maka cara 'cerdas' yang dilakukannya hanyalah berdamai dengan melakukan adaptasi kebudayaan. Oleh karena itu, keterlibatan 'kyai' dalam ritual Obong merupakan salah satu bentuk 'adaptasi' sekaligus 'resistensi' orang Kalang terhadap kekuatan 'mainstream' (Islam) (Kholiq, 2012: 228).

Bentuk resistensi lain terhadap arus islamisasi adalah munculnya folklore yang menyamakan 'nilai melaksanakan upacara obong sama dengan pahala melaksanakan ibadah haji'. Menyamakan Obong dengan ibadah haji adalah betuk dari strategi budaya orang-orang Kalang untuk meletakkan tradisi obong sederajat dengan salah satu kewajiban dalam ajaran Islam. Meskipun tanpa dasar, folklore ini bisa membangun kesadaran orang-orang Kalang santri tetap memandang penting -bahkan wajib melaksanakan tradisi leluhur Obong, walaupun harus dengan mengeluarkan biaya besar (Kholiq, 2012: 229).

Berdasarkan paparan di atas dapat ditarik pemahaman bahwa transmisi nilai-nilai keislaman pada masyarakat Kalang pada akhirnya melahirkan bentuk 'adaptasi' budaya, sehingga melahirkan reproduksi budaya yang mengakulturasikan antara nilai-nilai Islam dengan budaya Kalang. Proses transformasi budaya dalam masyarakat Kalang sampai sekarang masih terus berjalan. Oleh karena itu diperlukan pendekatan yang 
tepat untuk membangun sistem transmisi nilai-nilai keislaman sehingga nilainilai keislaman benar-benar bisa menyentuh aspek keyakinan orang-orang Kalang, tetapi tidak serta-merta mencerabut mereka sebagai komunitas budaya.

\section{Kesimpulan}

Berdasarkan keseluruhan paparan di atas, dapat di ambil kesimpulan sebagai berikut :

a. Pendidikan (Agama) Islam merupakan fasilitasi bagi terjadinya proses perubahan yang mengarah pada pembentukan kepribadian muslim. Orientasi tersebut mengindikasikan bahwa pendidikan (Agama) Islam menekankan pada proses internalisasi nilai-nilai Islam sehingga membentuk karakter dan watak peserta didik yang islami.

b. Orang Kalang membangun identitas budayanya berdasarkan nilai-nilai yang diwarisi dari leluhurnya. Mereka mempunyai sistem kepercayaan yang bersumber dari sejarah teologi Jawa purba dan adat istiadat yang digali dari 'mitologi' yang diyakini dan diwarisi secara turun temurun. Sistem kepercayaan dan nilai-nilai budaya Kalang ditransmisikan terhadap anak-anak Kalang melalui 'keluarga'. Pendidikan (Agama) Islam dalam konteks masyarakat Kalang dipahami sebagai transmisi nilai baru. Perjumpaan Islam dengan budaya Kalang akhirnya melahirkan bentuk 'adaptasi' budaya, sehingga melahirkan reproduksi budaya yang mengakulturasikan antara nilai-nilai Islam dengan budaya Kalang. 


\section{DAFTAR PUSTAKA}

Abdullah, Irwan, 2006, Konstruksi dan Reproduksi Kebudayaan, Yogyakarta: Pustaka Pelajar.

Abuddinnata, 2010, Ilmu Pendidikan Islam, Jakarta: Kencana

Achmadi, 2004, Idiologi Pendidikan Islam: Paradigma Humanisme Teosentrisme, Yogyakarta: Pustaka Pelajar.

Al Abrasy, M. Athiyah, 1979, Dasar-Dasar Pokok Pendidikan Islam, (terj.) Bustami A. Gani, Jakarta: Bulan Bintang.

Al Attas, Syed Muhammad al Naquib, Aim and Objectives of Islamic Education, Jeddah: King Abdul Aziz University.

Al Zarmuji, Burhan al Din, 1978, Ta'limu al Muta'allim Thariq al Ta'allum, Kudus: Menara Kudus.

Azizy, Qadri, 2002, Pendidikan (Agama) untuk Membangun Etika Sosial, Semarang: Aneka Ilmu.

Azra, Azyumardi, 2012, Pendidikan Islam: Tradisi dan Modernisasi di Tengah Tantangan Millenium III, Jakarta: Kencana.

Bourdieu, Pierre, 1996, “The Form of Capital” dalam John G. Richardson (ed), Handbook of Theory and Research for Sociology of Education, New York: Greenwood Press.

Daradjat, Zakiah, 2006, Ilmu Pendidikan Islam, Jakarta: Bumi Aksara.

Darwis, Djamaluddin, 2006, Dinamika Pendidikan Islam: Sejarah, Ragam dan Kelembagaan, Semarang: RaSAIL

Daulay, Haidar Putra, 2004, Pendidikan Islam dalam Sistem Pendidikan Nasional di Indonesia, Jakarta: Kencana.

DEPDIKBUD, 1989, Kamus Besar Bahasa Indonesia, Jakarta: Balai Pustaka.

Fajar, A., Malik, 1999, Reorientasi Pendidikan Islam, Jakarta: Fajar Dunia.

Geertz, Clifford, 1993, Kebudayaan dan Agama, Yogyakarta: Kanisius.

Hakim, Lukman, 2012, Internalisasi Nilai-Nilai Agama Islam dalam Membentuk Sikap dan Prilaku Siswa, Jurnal Pendidikan Agama Islam Ta'lim, Vol 10, Nomor 1, 2012.

Inglis, David, 2005, Culture and Everyday Life, London: Routledge Tylor \& Francis Group.

Jeanette R. \& T. Fortier, 2007, Cultural Memory: Resistance, Faith, and Identity, USA: University of Texas Press.

Juanda, 2010, "Peranan Pendidikan Formal dalam Proses Pembudayaan", Jurnal Lentera Pendidikan, Volume 13, Nomor 1 Juni.

Kesti, Maha, 1993, Upacara Kalang Obong di Gombong, Yogyakarta: Balai Kajian Sejarah dan Nilai Tradisional.

Ketjen E., 1883, Bijdrage tot de Geschiedenis der Kalangs op Java, TBG XXVIII.

Kholiq, Abdul, 2012, Islam Kalang: Politik Identitas Sub Etnis Jawa, Semarang: Lembaga Penelitian IAIN Walisongo.

Koentjaraningrat, 2002, Manusia dan Kebudayaan di Indonesia, Jakarta: Djambatan. 
Koentjaraningrat, 1987, Sejarah Teori Antropologi I, Jakarta: Universitas Indonesia Press.

Lombard, Dennys, 1996, Nusa Jawa Silang Budaya, Jakarta: Gramedia.

Marimba, Ahmad D., 1989, Pengantar Filsafat Pendidikan Islam, Bandung: Al Ma'arif.

Mudjahirin, 2006, Orang Islam Jawa Pesisiran, Semarang: Fasindo \& Puslit Sosial Budaya Lembaga Penelitian Universitas Diponegoro.

Muhaimin, 2004, Wacana Pengembangan Pendidikan Islam, Surabaya: PSAPM

----------, 2008, Paradigma Pendidikan Islam, Bandung: Remaja Rosda Karya, Bandung.

Mursi, Muhammad Munir, 1977, al Tarbiyah al Islamiyah Ushuluba wa Tattawnuruba fi Bilad al Arabiyah, Qahirah: Alam al Kutub.

Muslichin, 2008, Kalang dalam Perubahan Zaman: Studi tentang Tradisi Masyarakat Kalang di Wanglu Krajan, Semarang: Universitas Negeri.

---------, 2011, “Orang Kalang dan Budayanya: Tinjauan Historis Masyarakat Kalang di Kabupaten Kendal”, Jurnal Paramita, Vol. 21, No. 2 - Juli.

Nafis, M. Muntahibun, 2011, Ilmu Pendidikan Islam, Yogyakarta: Penerbit Teras.

Najwan, Johni, 2009, "Konflik Antar Budaya dan Antar Etnis di Indonesia Serta Alternatif Penyelesaiannya”, Jurnal Hukum, Edisi Khusus, vol. 16, Oktober.

Nakamura, Mitsuo, 1974, Bulan Sabit di Atas Pohon Beringin, Yogyakarta: Gadjah Mada University Press.

Narmoatmojo, Winarno, 2010, Pendidikan Nilai di Era Global, Makalah Seminar "Implementasi Pendidikan Nilai di Era Global", tanggal 22 September 2010, UNISRI Surakarta.

Pai, Young, 1990, Cultural Foundations of Education, Kansas: University of Missouri.

Poespowardojo, Soerjanto, 1989, Strategi Kebudayaan: Suatu Pendekatan Filosofis, Jakarta: Gramedia.

Pontjosutirto, Sulardjo, 1966, Beberapa Hal tentang Orang Kalang, Yogyakarta: Tesis sarjana sastra dan kebudayaan UGM.

Qadir, Zuly, 2009, "Kontektualisasi Religiusitas dan Kontestasi Publik: Agama di Dunia Modern", dalam Irwan Abdullah (ed), Dinamika Masyarakat dan Kebudayaan Kontemporer, Yogyakarta: Pustaka Pelajar.

Ramayulis, 2008, Ilmu Pendidikan Islam, Jakarta: Kalam Mulia.

Rasjidi, 1980, Strategi Kebudayaan dan pembaharuan Pendidikan Nasional, Jakarta: Bulan Bintang.

Rohidi, Tjetjep Rohendi, 2000, Ekspresi Seni Orang Miskin: Adaptasi Simbolik Terbadap Kemiskinan, Bandung: Penerbit Nuansa.

Sholeh, Ahmad, 2004, Upacara Obong, Semarang, Tesis S2, PPS IAIN Walisongo.

Siregar, Leonard, 2002, Antropologi dan Konsep Kebudayaan, Jurnal Antropologi Papua, Volume 1, Nomor 1, Agustus.

Spradley, James P., 1997, Metode Etnografi, terj. Elizabeth, Yogyakarta: PT. Tiara Wacana.

Sudaryanto, Agus, 1999, "Sistem Perkawinan pada Masyarakat Kalang: Studi Kasus di Kampung Ngoto dan Tegalgendu Yogyakarta”, Jurnal Mimbar Hukum, Universitas Gajah Mada. 
Sunyoto, Agus, 2012, Atlas Walisongo, Bandung: Pustaka Utama

Suparlan, 1981, Kebudayaan, Masyarakat dan Agama sebagai Sasaran Penelitian Antropologi, Jakarta: PLPA Departemen Agama RI.

Tilaar, H.A.R., 2002a, Pendidikan Kebudayaan dan Masyarakat Madani Indonesia, Bandung: Remaja Rosda Karya.

2002b, Perubahan Sosial dan Pendidikan: Pengantar Pedagogik. Transformatif untuk Indonesia, Jakarta: Grasindo. Karya.

2004, Paradigma Baru Pendidikan Nasional, Bandung: Remaja Rosda dan Sutaryadi, 1994, Analisis Kebijakan Pendidikan, CEt. II, Bandung: Remaja Rosda Karya.

Tylor, E. B., 1871, Primitive Cultures; Researches Into The Development of Mythology, Philosophy, Religion, Language, Arts and Custom. London: John Murray.

Warto, 2011, "Kalang, Pesanggem, dan Sejarah Kaum Marjinal", Jurnal Sejarah CITRA LEKHA, Vol. XV, No. 1 Februari. 